Limnological Review (2012) 12, 4: 179-190

DOI 10.2478/v10194-012-0058-0

\title{
Over 200 years of drainage practices and lake level drawdown in the Uściwierskie Lowering (Łęczna-Włodawa Lakeland)
}

\author{
Grzegorz Kowalewski
}

Department of Biogeography and Palaeoecology, Adam Mickiewicz University, Dzięgielowa 27, 61-680 Poznań, Poland, e-mail: ichtys@amu.edu.pl

\begin{abstract}
Meliorations of the Łęczna-Włodawa Lakeland have considerably determined its water relations within the last more than 200 years. The analysis of the map by Anton Mayer von Heldensfeld, so far not applied in studies on the drainage network of this lakeland, executed in the years 1801-04, revealed the drainage of the Uściwierskie Lowering already at the turn of the $18^{\text {th }}$ and $19^{\text {th }}$ century. This shifts the commencement of strong anthropogenic impact on this area to a considerably earlier period than was previously assumed. The lakes subject to analysis (Rotcze, Uściwierz, Bikcze, and Lakes Piaseczno and Łukie neighbouring with the Lowering) were incorporated into the drainage system in various periods. Such incorporation of a water body involved water level drawdown. The water level decreased first in Lake Bikcze, and the latest in Lake Rotcze. More detailed information on changes in the water level in the lakes of the Uściwierskie Lowering since 1882 was obtained based on calculation and on comparison with current data of measurements conducted by Rostworowski. The analysis revealed that the water level in Lakes Bikcze and Piaseczno, although fluctuating, has not changed within the last 130 years, whereas the water level in Lake Uściwierz decreased by $33 \mathrm{~cm}$, and in Lake Rotcze by $90 \mathrm{~cm}$.
\end{abstract}

Key words: Łęczna-Włodawa Lakeland, Uściwierskie Lowering, artificial drainage, drainage network, water level fluctuations, Heldensfeld's map

\section{Introduction}

Water represents a constitutive element shaping the ecosystems of the Łęczna-Włodawa Lakeland. Within the last centuries, it has been subject to systematic, continuously increasing anthropopressure (Chmielewski and Radwan 1993). One of its symptoms is the development of drainage systems, leading to the incorporation of lakes in the drainage network (Wilgat 1991). As a result of those two processes, the character of lakes changes from closed- to open-drainage, and a decrease in the water level and reduction of maximum stages occur. Although natural processes also lead to the development of a drainage network, the human melioration practices substantially accelerate the process. Moreover, a change in the character of a lake from closed- to open-drainage or flow-through by its incorporation in the drainage system results in a number of not only hydrological, but consequently also hydrobiological changes.

In the Łęczna-Włodawa Lakeland, melioration activities were conducted with particular intensity, because after the $2^{\text {nd }}$ World War, access to many settlements in the melting season was still very difficult. The most intensive works were conducted since 1954, in connection with the construction of the WieprzKrzna Canal, completed in 1961 (Wilgat et al. 1991, Michalczyk 1994b). According to Rostworowski (1882, p. 77), melioration of the Łęczna-Włodawa Lakeland was "an issue already existing for a long time in the form of a project of a canal from the Wieprz to the Bug River" ["kwestyją istniejącą od dawna w formie projektu kanału od Wieprza do Bugu"]. Meliorations resulted in increased runoff of surface waters and a decrease in the level of groundwaters, as well as transformation of peatlands into muck (Michalczyk 2009). In the years 1952-92, 5 out of 68 lakes existing in the lakeland disappeared completely (Chmielewski and Chmielewski 2010).

Due to this, literature relatively frequently undertakes the issue of anthropogenic changes in water relations. Meliorations in the Łęczna-Włodawa Lakeland are reconstructed based on historical maps and aerial photographs. Whereas changes in the drainage 
system occurring in the Łęczna-Włodawa Lakeland within the last 50-100 years are thoroughly studied (e.g. Chmielewski and Radwan 1993; Michalczyk 1994b, Michalczyk 2009), much less is known on changes occurring before. The oldest cartographic source consulted by authors is the Quartermaster Map, presenting the situation from the 1830's (Dawidek and Turczyński 2007). Meanwhile, a remarkable, although so far unused source is constituted by maps by Anton Mayer von Heldensfeld, presenting the state of the drainage network from the turn of the $18^{\text {th }}$ and $19^{\text {th }}$ century. Although the maps are not cartometric, they were prepared at a large scale, and show the presence of hydrographic objects with high precision.

Another, still very innovative, source of information on the functioning of the lakes and wetlands of the Łęczna-Włodawa Lakeland is palaeogeographical studies (palaeoecological, palaeolimnological). These fields of study have so far focused on longterm changes occurring during the Late Glacial and Holocene (e.g. Kulesza et al. 2012). Much less attention was paid to high-resolution analyses regarding the last centuries (e.g. Kaczorowska and Kornijów 2012; Kowalewski et al. in press). These analyses fulfil a more significant role here, especially that only they reach sufficiently far into the past to permit a study on the natural rhythm of changes unaffected by man because. "a serious obstacle in the determination of anthropogenic changes in water relations constitutes their overlapping with the natural evolution of the hydrosphere" (Wilgat 1991, p. 206).

The objective of the paper is to determine, based on maps from the years 1801-1804 and their later scaled down copy, as well as the paper by Rostworowski (1882), the period in which the incorporation of the lakes of the Uściwierskie Lowering in the drainage network occurred, and the effect of the process on water level fluctuations in those lakes.

\section{Study area and methods}

In terms of natural flora and fauna resources the Uściwierskie Lowering is a part of the ŁęcznaWłodawa Lakeland of unique value. Land restoration measures have been conducted there since the 1990's (Chmielewski and Radwan 1993). Parts of it are under various forms of nature protection. It was also proposed to include the entire area of the Lowering in the Poleski National Park (Chmielewski and Sielewicz 1994).
The Uściwierskie Lowering was originally the second largest (after Krowie Bagno wetland) closeddrainage depression, with an area of $45.83 \mathrm{~km}^{2}$ (Sposób and Turczyński 2009). Closed-drainage areas originally occupied $43 \%$ of the Łęczna-Włodawa Lakeland. Human activity resulted in dissecting of the natural watersheds and drainage of the internal part of the lakeland, with its waters discharged to the Bug and Tyśmienica Rivers (Sposób and Turczyński 2009). The percentage of closed-drainage areas determines the unique character of the lakeland. In the old glacial zone, closed-drainage areas occupied $2 \%$ of its area, and in the young glacial zone 12-16\% (Kowalska 1970). The Uścimowskie Lowering was originally filled with waters of probably a single lake with a number of islands and a very fragmented shoreline. It is currently filled with limnic sediments and peats (Okruszko 1971). Only in the deepest ( $>10 \mathrm{~m})$ parts of the original lake basin, shallow lakes still exist, usually surrounded by rushes and floating mat (Sposób and Turczyński 2009). On the southern side, the Uściwierskie Lowering is closed by the Garbatówka Hump, composed of marls and Upper Cretaceous limestone, locally covered with sands and silts. The incorporation of the Lowering in the drainage network resulted in the development of the Piwonia Dolna Stream. A part of the Lowering is located within the range of activity of the mining area of KWK "Bogdanka" (Sposób et al. 2010). The most substantial anthropogenic transformations in the Lowering occurred in the years 19501990, and led to considerable degradation of the area (Chmielewski and Radwan 1993).

The analysis of changes in the drainage system was conducted with the application of Carte of West-Gallizien by Anton Mayer von Heldensfeld, prepared in the years 1801-1804. The map was published in 1804 in the form of 275 coloured sheets at a scale of $1: 28,800$. This paper applies sheet 233 supervised in the field by lieutenant (Oberlieutenant) Wilhelm Tielke (Sawicki 1928). Unfortunately, the maps were created not based on reliable geodesic methods, but based on a rough triangulation network. Therefore, conducting measurements on the maps is not possible. However, the hydrographic content was presented in great detail."Wie fein getont erscheinen die Ströme, wie lebendig die Altwässer, verwilderten Stomarme, [...] die gesonderte Darstellung der periodisch tätigen Flusse, erscheint hier schon durchgeführt. Quelltümpel, Sumpfe, Alluvialwiesen, Teiche mit sorgfältiger Dammzeichnung umgeben, weisen vielfach Signa- 
turen auf, die lebhaft an die heute gebrauchten erinnern" (Sawicki 1928, p. 75). In later years, several maps scaled down based on the sheets at a scale of 1:28,800 were published, including a 12 -sheet map at a scale of $1: 172,800$, prepared by Hieronymus Benedicti in 1808 , and also used in this paper. The map involves numerous intentional deformations in relation to the original, but mainly concerning the land relief. Sawicki does not mention any inaccuracies in the representation of the drainage network.

The analysis of changes in water level ordinates was conducted based on the comparison of levelling measurements by Rostworowski (1882) with modern measurements of the water level in the lakes (Michalczyk et al. 2011) and the elevations presented on the topographic map at a scale 1:10,000 (coordinate system 1965) from 1976. Results of the measurements by Rostworowski in cubits and inches were recalculated to the metric system, where: 1 inch $=0.0248 \mathrm{~m}, 1$ cubit $=0.596 \mathrm{~m}$.

\section{Results}

Changes in the natural and artificial drainage system

The drainage system, both artificial and natural, on the map by Heldensfeld from 1804 (Fig. 1a) is much more developed than that presented on the Quartermaster Map from 1839 (Fig. 2). On the latter map, the hydrographic content is presented in a very inconsistent manner. Ditches start near a road, and end on a road, or near settlements. Lack of continuity of the ditch between Lakes Bikcze and Łukie is particularly significant. The issue whether this results from the low precision of the map or overgrowing (disappearance) of a number of ditches remains unexplained.

The map by Heldensfeld documents the existence of a ditch between Lakes Uściwierz and Bikcze (on the map referred to as Usciwiersz and Bliczonka, respectively), as well as ditches from Lakes Ciesacin and Uściwierzek. The latter is also fed by a ditch draining wetlands located to the south (Fig. 1a). Moreover, the map by Heldensfeld (Fig. 1ab) shows a number of natural streams, as suggested by their sinusoidal course. In the map legend, streams (Bächen) "werden fein mit blauer Dinte (veraltet Tinte - ink - author's note) gegeben [...] mit zahlreichen, oft phantastischen Mäanderwindungen", whereas "Kanäle und Wasserleitungen erscheinen blau, aber geradlinig und eckig" (Sawicki 1928, p. 66). One of the streams flows from Lake Sumin (on the map referred to as Piskorze) to Lake Uściwierz, and another, depicted on the version of the map at a smaller scale (Fig. 1b), from Lake Nadrybie (on the map referred to as Bikcze) to Lake Bikcze. The third stream drains wetlands located south of Lake Uściwierz, between the modern villages of Wólka Nadrybska and Garbatówka, and flows into Lake Uściwierz between the stream draining Lake Sumin and the ditch from Lake Ciesacin (Fig. 1a). The drainage ditch flowing into Lake Uściwierz from SE, existing on the Quartermaster Map (Fig. 2), constitutes remains of the stream. Two streams, one connecting Lakes Uściwierz and Nadrybie, and another flowing into Lake Uściwierzek from the west, are only depicted on the map by Heldensfeld at a smaller scale (Fig. 1b).

In relation to the streams presented on the map by Heldensfeld, a hypothesis of their natural genesis can be stated. Draining of Lakes Bikcze and Uściwierz resulted in a decrease in the water level in the lakes. This consequently led to a considerable difference in water levels between those lakes and those located in the southern and eastern part of the Lowering. The existence of the difference in the water level could cause drainage from the higher located lakes, leading to the development of streams draining them, and consequently to a water level drawdown in those lakes, including Lake Sumin. Ditches in which the streams flowed were used later as drainage ditches. Therefore, a decrease in the water level in the Uściwierskie Lowering both resulted from stricte anthropogenic activities, and were a consequence of the developing natural processes.

The map by Heldensfeld does not show any streams draining Lake Rotcze (referred to as Ciesiaczyn). Therefore, the lake can be recognised as the only one of the lakes of the Uściwierskie Lowering which still retained (at least partly) its natural water level 200 years ago. It is much larger on the map than on maps from later periods, but due to the quality of the map, it would be risky to draw any significant conclusions from this fact.

\section{Changes in lake water levels}

Rostworowski (1882) conducted levelling, as he writes, "While studying the issue of the drawdown of Lake Łukie, constituting my property, I conducted levelling of some local lakes, and the result of the study is as follows:..." ["Badając kwestyją spuszczenia jeziora Łukiego, będącego moją własnością, robiłem 


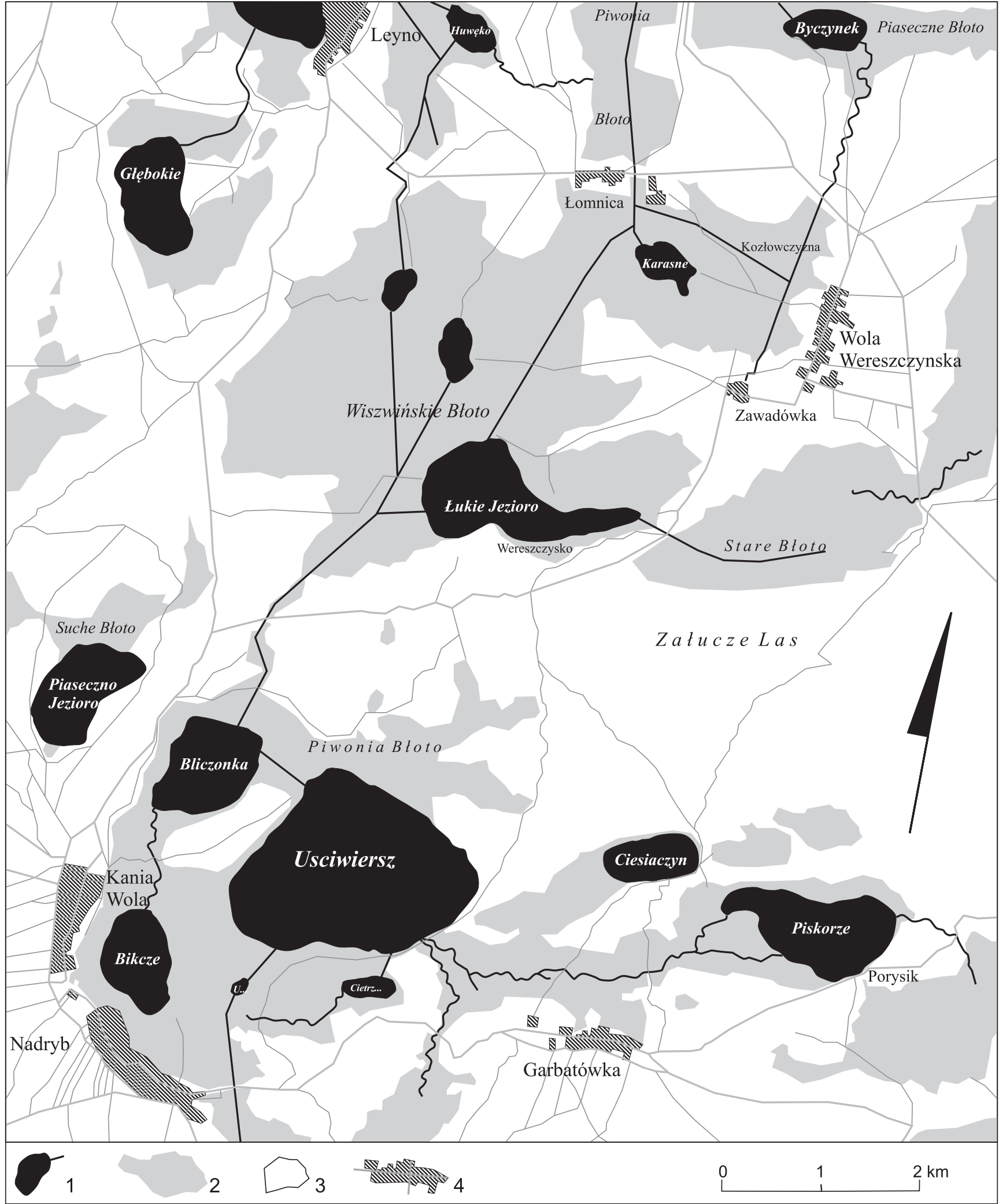

Fig. 1a. Land cover and drainage system redrawn from the Heldensfeld Map from 1804 (scale 1:28,800, sheet 233). Explanation: 1 - lake and water courses, 2 - treeless wetland, 3 - fields and forests, 4 - villages and roads. 


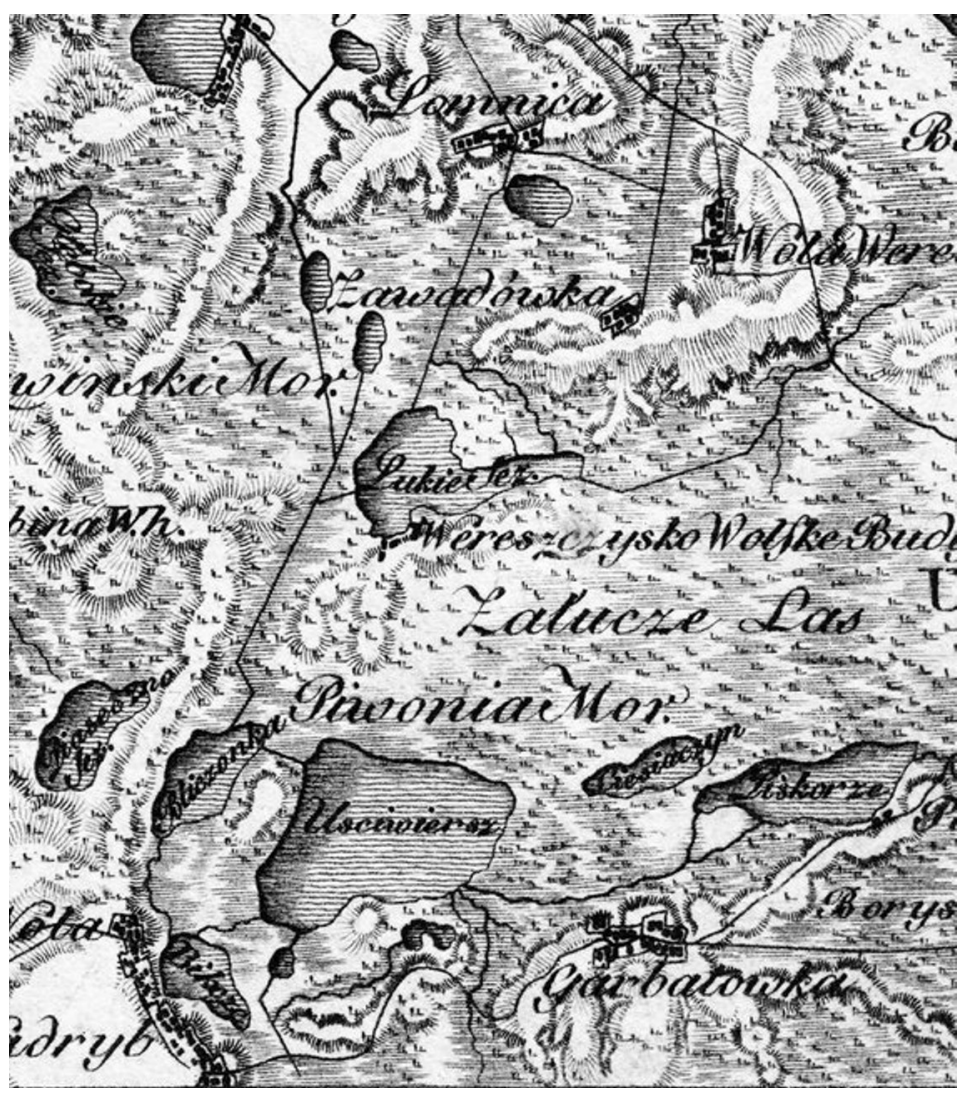

Fig. 1b. Heldensfeld Map at a scale 1:172,800, showing the same area as in Fig 1a.

niwelacyją niektórych okolicznych jezior i rezultat tych poszukiwań jest następujący:...”] (op. cit., p. 76). It should be highlighted that on the map in the work cited (Fig. 3), the ditch draining the Uściwierskie Lowering (Bikcze-Łukie) is clearly depicted, although "my plan is prepared based on a detailed map executed by the Quartermaster of the former Polish army, and economic maps of the neighbouring properties" ["Planik mój zrobiony jest na podstawie mapy szczegółowej, dokonanej przez kwatermistrzostwo b. wojsk polskich, oraz map ekonomicznych sąsiednich majątków"] (op. cit., p. 76), and the ditch does not exist on the Quartermaster map. On the map by Rostworowski, also ditches connecting Lakes Uściwierz and Bikcze are depicted, although the ditch on the side of Lake Sumin only begins near the road, similarly as on the Quartermaster map. Lake Rotcze still had no outflow.

From the point of view of hydrographic analyses, the information on elevation differences between the lakes of the Uściwierskie Lowering, specified in the work, was much more significant than the map itself. The results of levelling measurements were provided by Rostworowski in cubits and inches. The values were converted to the metric system (Table 1), and compared with values provided on the map 1:10,000 (coordinate system 1965) and data presented by Michalczyk et al. (2011). The results are presented in Fig. 4.

Because Rostworowski referred the elevations to the level of the currently non-existent, "almost completely drained" Lake "Wielkie near Leyno", this level has to be determined. A detailed analysis of the disappearance of the lake was presented by Mięsiak et al. (2005). The difference in elevation between the outmost lakes (Wielkie and Rotcze) in the work by Rostworowski (1882) amounted to $7.52 \mathrm{~m}$. On the topographic map from 1976, the elevations of the lowest points (within drainage ditches) in the basin filled by Lake Wielkie amount to 163.0 and $163.4 \mathrm{~m}$ a.s.l. Therefore, the ordinate of the lake should be higher. On the other hand, the level of Lake Rotcze could not exceed the elevation of $171.25 \mathrm{~m}$ a.s.l., as results from the relief of its basin. The level of Lake Wielkie could not be higher than $163.73 \mathrm{~m}$ a.s.l. (= $171.25-7.52)$. It was also assumed that the level of the lakes in 1882 could not be lower than in the modern times. The mean level of Lake Bikcze from the years 1991-96 amounted 


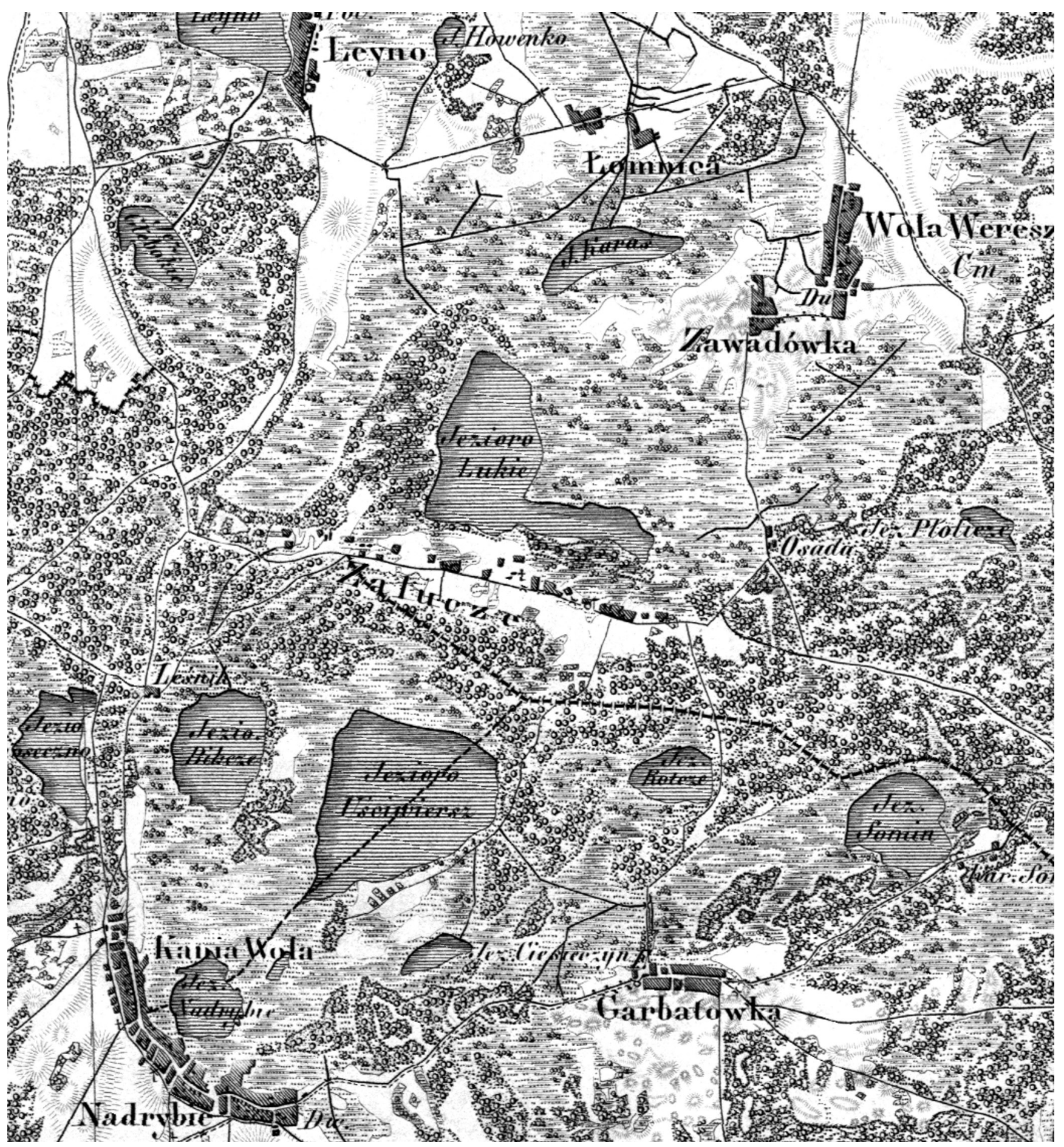

Fig. 2. Section of the Quartermaster Map from 1839, showing the same area as in Fig 1a.

to $169.25 \mathrm{~m}$ a.s.1. (Michalczyk et al. 2011). After subtracting the difference calculated by Rostworowski, the level of Lake Wielkie amounts to $164.54 \mathrm{~m}$ a.s.l. (= $169.25-5.71)$. This value seems probable, and is within the range calculated above $(163.4 \div 163.73 \mathrm{~m}$ a.s.1.). Therefore, it was adopted for further calculations.
The water level of a lake depends on the water balance of its catchment, whereas its incorporation in the drainage system increases the output. The highest water levels within the last 40 years, as indicated by data for Lake Piaseczno (Michalczyk et al. 2011), occurred during the preparation (1976) of the topo- 


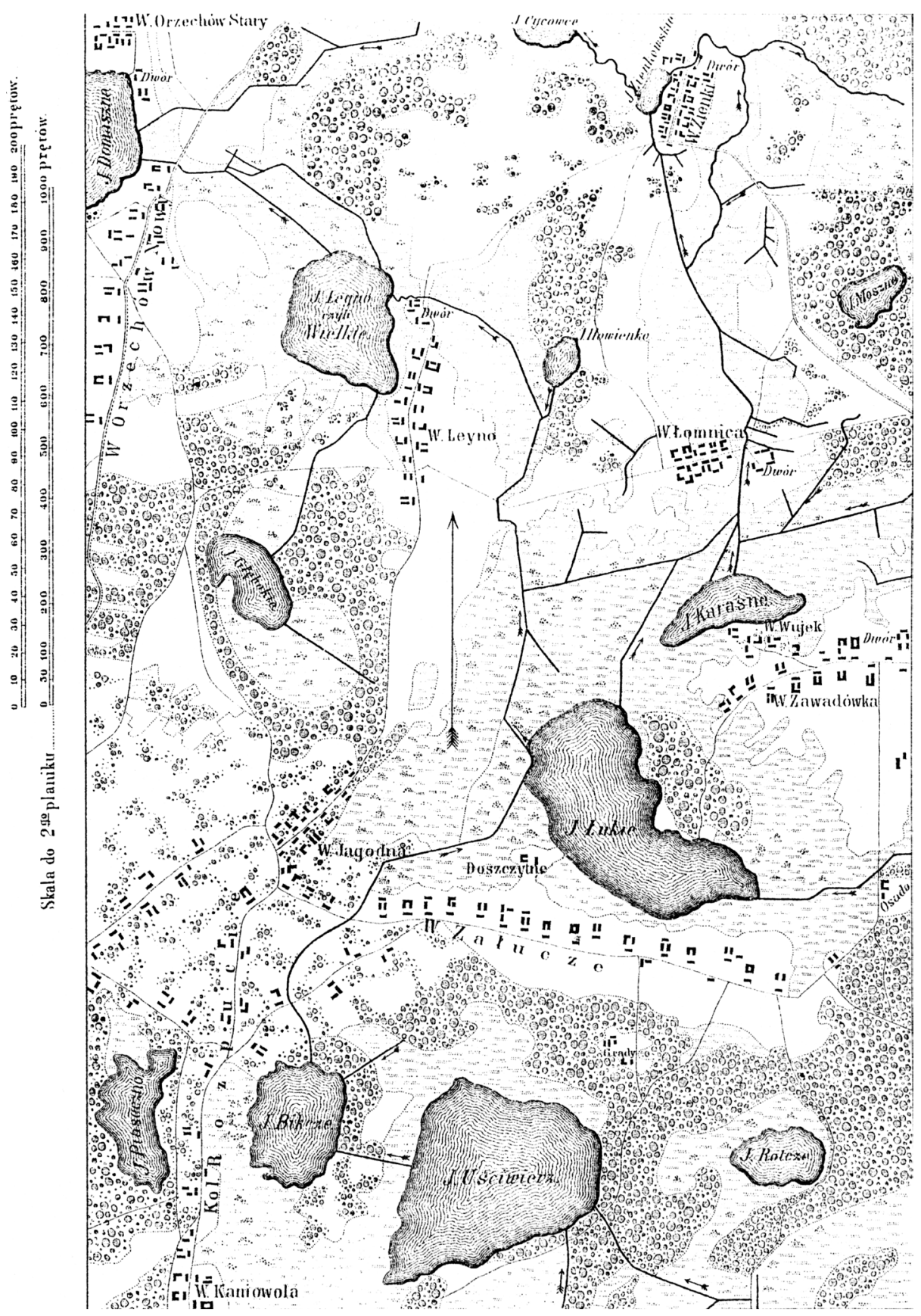

Fig. 3. Map from the paper written by Rostworowski (1882).

graphic map 1: 10,000 (coordinate system 1965). The highest recorded water levels occurred here in the years 1975-76 (max. $170.8 \mathrm{~m}$ a.s.l.) and 1981-82 (max. $170.75 \mathrm{~m}$ a.s.l.) (Michalczyk et al. 2011). The water level in Lake Piaseczno on the map is higher than that in Lake Rotcze by $0.3 \mathrm{~m}$. Meanwhile, the average level of Lake Piaseczno in the years 1991-2010 is lower than in Lake Rotcze by $0.8 \mathrm{~m}$. Only in the years of the highest water levels, the difference decreased to 0.6 $\mathrm{m}$, and extremely to $0.4 \mathrm{~m}$ (spring 2002) (Michalczyk et al. 2011). This suggests that hydrologically closed Lake Piaseczno is much more susceptible to fluctuations resulting from variable precipitation than the drained lakes of the Uściwierskie Lowering. Therefore, data from the work by Michalczyk et al. (2011) were adopted for the analysis of changes in the water level of the Uściwierskie lakes. 
Table 1. Recalculation of measurements made by Rostworowski (1882) and calculation of water level changes

\begin{tabular}{|c|c|c|c|c|c|c|c|}
\hline & \multicolumn{2}{|c|}{$\begin{array}{c}\text { Measurements } \\
1882\end{array}$} & \multirow[t]{2}{*}{$\begin{array}{c}\text { Recalculated } \\
\text { measurements } \\
1882 \text { showing } \\
\text { exceedance over } \\
\text { estimated water } \\
\text { level of Lake Wielkie } \\
\text { (Leyno) } \\
\text { A }\end{array}$} & \multirow[t]{2}{*}{$\begin{array}{c}\text { Estimated water } \\
\text { level of Lake Wielkie } \\
\text { (Leyno) in } 1882 \\
\text { and } \\
\text { average current } \\
\text { lake level acc. to } \\
\text { Michalczyk et al. } 2011 \\
\text { B }\end{array}$} & \multirow[t]{2}{*}{$\begin{array}{c}\text { Exceedance of current } \\
\text { lake level in comparison } \\
\text { with estimated water } \\
\text { level of Lake Wielkie } \\
\text { (Leyno) } \\
(=\text { B-163.54) } \\
\text { C }\end{array}$} & \multirow[t]{2}{*}{$\begin{array}{c}\text { Difference } \\
\text { between } \\
\text { C and A } \\
(=C-A) \\
D\end{array}$} & \multirow[t]{2}{*}{$\begin{array}{c}\text { Estimated lake } \\
\text { level in } 1882 \\
\text { (=B-D) } \\
\text { E }\end{array}$} \\
\hline Lake & cubit & inch & & & & & \\
\hline Wielkie (Leyno) & 0 & 0 & 0 & 163.54 & & & \\
\hline Zienkowskie & 0 & 12 & 0.30 & & & & \\
\hline Karaśne & 7 & 11 & 4.44 & & & & \\
\hline Łukie & 8 & 16 & 5.16 & 168.00 & 4.46 & -0.70 & 168.70 \\
\hline Bikcze & 9 & 14 & 5.71 & 169.25 & 5.71 & 0.00 & 169.25 \\
\hline Piaseczno & 9 & 23 & 5.93 & 169.49 & 5.95 & 0.02 & 169.47 \\
\hline Uściwierz & 10 & 13 & 6.28 & 169.49 & 5.95 & -0.33 & 169.82 \\
\hline Rotcze & 12 & 15 & 7.52 & 170.16 & 6.62 & -0.90 & 171.06 \\
\hline
\end{tabular}

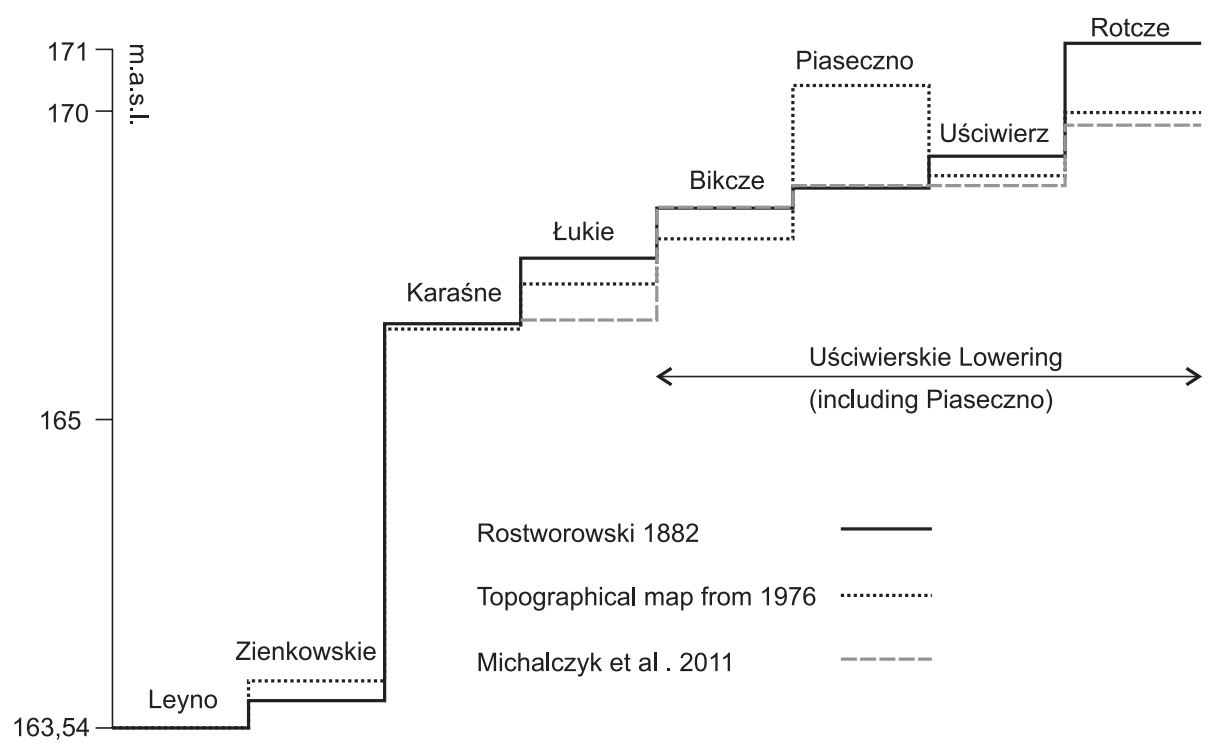

Fig. 4. Elevation of lakes acc. to Rostworowski (1882), topographical map from 1976 (coordinate system 1965) and mean values acc. to Michalczyk et al. (2011).

In comparison to the mean water levels provided by Michalczyk et al. (2011), the water level of Lakes Bikcze and Piaseczno measured by Rostworowski (1882) remained unchanged, and that for Lakes tukie, Uściwierz, and Rotcze decreased (Fig. 4). Assuming the average groundwater level during levelling made by Rostworowski (and the precipitation data for Warsaw suggest such a level - see Przybylak 2010), the average water level in Lake Piaseczno did not change within the last 130 years. Considering the insignificant effect of drainage on the lake, this is possible. It is more surprising that the water level of Lake Bikcze did not change. This fact, however, confirms the advanced degree of drainage of the lake already in 1882, which does not come as a surprise, considering that it was already drained in 1804. The degree of drainage of Lakes Uściwierz and Rotcze was different. The water level in Lake Uściwierz decreased by $0.33 \mathrm{~m}$, and in Lake Rotcze by as much as $0.9 \mathrm{~m}$ (Table 1). The elevation of Lake Rotcze according to this calculation would amount to as much as 171.06 $\mathrm{m}$ in 1882, which seems to be a probable value. It is a level more than $0.5 \mathrm{~m}$ higher than the highest level 
measured in modern times, when it amounted to 170.5 $\mathrm{m}$ a.s.l. (Michalczyk et al. 2011). Such a high water level in Lake Rotcze still occurring (at the average water level) at the end of the $19^{\text {th }}$ century is on the one hand documented by the lack of effect of meliorations on the lake, and on the other hand suggests a potential past water level for the entire Uściwierskie Lowering, formerly constituting one lake, as convincingly evidenced by Okruszko et al. (1971). The past existence of one, strongly fragmented lake is moreover suggested by the land relief (a mineral threshold closing the Uściwierskie Lowering at the elevation of approximately $171 \mathrm{~m}$ a.s.l.) and toponymy (the Ostrówek village between Lakes Bikcze and Uściwierz, as well as the Ostrów Nadrybski village south of Lake Uściwierz). Ostrówek is an island among wetlands and lakes. It was already connected by a road with Kaniwola village on Heldensfeld's map from 1804.

\section{Discussion}

The determination of the time of commencement of transformations of the drainage network of the Łęczna-Włodawa Lakeland, and particularly the originally closed-drainage Uściwierskie Lowering, is a problematic issue due to the scarcity of sources. It cannot be solved by the exclusive application of cartographic methods. It also requires palaeogeographical (palaeohydrological and palaeolimnological) analyses, and analyses of available historical and archaeological materials. This paper constitutes a cartographichistorical contribution to solving this subject.

The issue of anthropogenic transformations of the Uściwierskie Lowering has been discussed in other papers, beginning with the pioneer works by Wilgat (1954, 1957), among other things addressing the issue of closed-drainage areas numerous in the ŁęcznaWłodawa Lakeland. Sposób and Turczyński (2011), as well as Michalczyk (1994b) determine the beginning of melioration works to the $18^{\text {th }}$ century. In relation to the Uściwierskie Lowering, Sposób and Turczyński (2011) mention considerable development of the drainage system in the Lowering between the $1^{\text {st }}$ and $2^{\text {nd }}$ World War. Suchożebrska and Chabudziński (2007) determined only slight transformations of the drainage system of the Lowering according to the map from 1839: "The hydrographical situation presented there had not been transformed by man in any significant way. Only in the Ciesacin catchment was there a single ditch draining the northeastern part and infringing its natural bor- ders" (op. cit. p. 226). Also in the paper by Sposób et al. (2010), the drainage of the Lowering around 1830 was not noted. The analysis of the map by Heldensfeld shifts the time of incorporation of the Uściwierskie Lowering into the drainage system at least to the turn of the $18^{\text {th }}$ and $19^{\text {th }}$ century. It remains to be determined when the mineral threshold confining the Lowering to the north was dug through for the first time.

The analysis of water level fluctuations, based on changes in the lake's surface area, is not very precise, especially that in the case of the lakes of the Uściwierskie Lowering, the determination of the surface area of the lake is problematic (Turczyński et al. 2009). Therefore, it is better to base the study on the available data regarding the water level, and the analysis of the land relief. The majority of the lakes of the Lowering were incorporated into the artificial drainage system before the measurements conducted by Rostworowski (1882). His levelling provides water levels of already meliorated lakes.

Lake Rotcze does not fit the pattern described. The decrease in its level is much higher in relation to that in 1882 than in the case of Lake Uściwierz, the level of which was significantly lowered already before 1882, or Lake Bikcze, the level of which was already stabilised in 1882 . The water level in Lake Rotcze could have begun to decrease along with the execution of a drainage system west of the lake between 1918 and 1936, documented on the WIG map $1: 100,000$. This could be related to the practices of the owner of Lake Rotcze and heir of Garbatówka, Józefowicz. In the 1920's, he planned to develop fish farming in Lakes Rotcze and Uścimowskie, but as a result of the economic crisis, the lake was taken over by a bank (Panasiuk 2012). After the $2^{\text {nd }}$ World War, significant changes were caused by the construction in the 1950's of the irrigation ditch Bogdanka-Wola Wereszczyńska, running along the northern shore of the lake and being usually empty. The lake's water level probably decreased the fastest after 1963, when according to Panasiuk (2012), "activities were commenced aimed at «the improvement of habitat conditions», with the purpose of transforming Lakes Uściwierz, Nadrybie, and Bikcze into retention reservoirs. The plan was not successful, but the wetland surroundings were irreversibly changed. Assemblages of variable-moisture Molinion meadows with elements of Poa pratensis and Festuca rubra replaced hay meadows and pastures. The shoreline of the lake became overgrown with osier shrubs. The constructed irrigation ditch Wola 
Wereszczyńska-Bogdanka is not used, and the water level in the surrounding lakes decreased by approximately one meter." Therefore, the construction of the drainage system in the 1920's probably did not cause a significant decrease in the water level in the lake. The highest decrease occurred in the 1960's.

The level of Lake Uściwierz, already drained before 1804, decreased to a lesser extent, but part of the decrease occurred in the second half of the $20^{\text {th }}$ century, as indirectly documented by Chmielewski S. and Chmielewski T.J (2009). The surface area of Lake Uściwierz according to the authors cited decreased in the years $1952-2007$ by approximately $8 \%$, and the area of the open water by approximately $27 \%$ (Chmielewski S. \& Chmielewski T.J 2009). The surface area of Lake Piaseczno decreased by approximately $4 \%$, and its open water area by approximately $11 \%$. The issue of the water levels at the moment of conducting the measurements was not addressed, however. Whereas for 2007, they amounted to 169.3-169.4 m.a.s.l. for Lake Piaseczno, and 169.4-169.5 m.a.s.l. for Lake Uściwierz (Michalczyk et al. 2011), and were average, we do not know their level from 1952. Although the year 1952 was wet, the preceding year, 1951, was very dry. Earlier data do not exist. The existing data for Warsaw, correlating with data for Lublin and Włodawa, show average amounts of precipitation for that time. In spite of this fact, phenomena like the disappearance of numerous peatland areas, excavation and an increase in forest areas unequivocally suggest a decrease in the water level in the lakes of the Uściwierskie Lowering (Chmielewski S. and Chmielewski T.J 2009).

Another problematic issue appears here. The comparison of measurements by Rostworowski and modern-day measurements revealed that the level of Lake Bikcze did not change. Chmielewski S. and Chmielewski T.J (2009) determined a general tendency for drainage of the area in the years 1952-1992 (2007), however. Therefore, either the decrease is only apparent, and the water loss only results from overgrowing by vegetation, or my measurements are inaccurate. The inaccuracy would involve too low estimation of the reference level of Lake Leyno Wielkie. However, with another reference level adopted, the level of Lake Rotcze would be even higher, which is very improbable. A third possibility would be a mistake in measurements by Rostworowski. In my opinion, the first option is the most probable, because the determination of the shoreline of Lake Bikcze, as a lake surrounded by peatlands and reed rushes, is practically impossi- ble (Turczyński et al. 2009), and Chmielewski S. and Chmielewski T.J (2009) analyse not the surface area of the lake, but the area of the water surface.

A decrease in the water level in the Uściwierskie Lowering after the 1950's is also confirmed by the level of the nearby groundwater gauge Ludwin, recorded from 1951, indicating levels over $0.5 \mathrm{~m}$ higher during the entire decade of the 1950's in relation to the following years (Michalczyk 1994a), and the general evaluation of the results of draining, conducted with particular intensity from the mid-20 $0^{\text {th }}$ century. According to Wilgat et al. (1991) "Man has interfered with them [drainage network] for a long time, mainly by regulating river channels and digging ditches draining excess water, which in a flat, sandy area was not difficult, and by the incorporation in the drainage network of lakes and closed-drainage depressions. The effects of the practices were very visible, but did not significantly affect the character of drainage network. A feature distinguishing the lakeland was still the extensive area of wetlands. After the $2^{\text {nd }}$ World War, access to some villages was still impossible during the spring melt season. The extensive peatlands turned into inaccessible wetlands. Significant changes are related to the construction of the melioration system of the Wieprz-Krzna Canal. ... The construction of agricultural drainage systems resulted in a decrease in the groundwater level in a number of places, drying wetland areas, and acceleration of the spring runoff. ... Parts of the area not related to the Canal have their own drainage systems, some of which were executed a long time ago and restored in the latest years, and some were developed from scratch." (op. cit. p. 48n). This long quotation is a good representation of the general hydrological changes occurring in the ŁęcznaWłodawa Lakeland during the second half of the $20^{\text {th }}$ century. It seems, however, that the occurrence of significant changes in the drainage system only after the $2^{\text {nd }}$ World War in the case of the Uścimowskie Lowering only concerns Lake Rotcze. The remaining lakes were subject to transformations already at the turn of the $18^{\text {th }}$ and $19^{\text {th }}$ century.

\section{Conclusions}

The artificial drainage system in the Uściwierskie Lowering existed already at the turn of the $18^{\text {th }}$ and $19^{\text {th }}$ century. All lakes except for Lake Rotcze were incorporated into drainage network. Such a condition was still unchanged in 1882, as suggested by the map 
by Rostworowski. The much scarcer and intermittent drainage system on the Quartermaster Map from 1839 requires explanation.

Drainage of lakes by means of drainage ditches led to a lake level drawdown, and consequently, their surface areas also decreased. Lake level drawdown also caused faster development of rush vegetation and macrophytes in the lake's basin, accelerating the disappearance of the lake. Decreases in the water level occurred in an uneven manner. The latest decrease, probably only from the mid- $20^{\text {th }}$ century, concerned Lake Rotcze. The earliest changes concerned the water level in Lake Bikcze which - after digging a ditch draining the lake to the north - stabilised at the beginning of the $19^{\text {th }}$ century.

In order to understand the degree of anthropogenic transformations of the drainage network, knowledge on its natural changes is required. Therefore, the reconstruction of water level fluctuations in Polesie within the last 200-500 years is urgently required, particularly involving palaeolimnological and telmatological studies (Tobolski 2000) and studies of historical sources recording at least extreme facts. Only then is it possible to fully analyse anthropogenic changes.

In order to estimate water level fluctuations based on aerial photographs and cartographic sources, knowledge on the water level in the observation period is required. This was emphasised by, among others, Chmielewski and Radwan (1993), Dawidek and Turczyński (2007), as well as Turczyński et al. (2009). The knowledge is necessary for the accurate interpretation of changes in the lake's water level, surface area, and volume.

It is desirable to prepare a study project involving the purchase and analysis of the original maps by Heldensfeld at a scale of 1:28,800 for the entire lakeland. In spite of the lack of cartometrics, the maps include invaluable, not only hydrographical, information, and will permit the documentation of the degree of anthropogenic transformations of the drainage system at the turn of the $18^{\text {th }}$ and $19^{\text {th }}$ century.

\section{Acknowledgement}

The study was supported by the State Committee for Scientific Research, project No. P06S00127. Ryszard Kornijów, Magda Suchora and anonymous reviewer are acknowledged for their constructive comments on the early version of this manuscript.

\section{References}

Chmielewski J.T., Harasimiuk M., Łoś M., Michalczyk Z., Pawłowski L., Radwan S., 1992, Próba renaturalizacji stosunków ekologicznych w zespole jeziorno-torfowiskowym Pojezierza Łęczyńsko-Włodawskiego (An attempt at the restoration of ecological relations in a lake-peat-bog system of the Łęczna-Włodawa Lake District), [in:] Chmielewski T.J, Richling A., Wojciechowski K.H. (eds), Funkcjonowanie i waloryzacja krajobra$\mathrm{zu}$ (Functioning and evaluation of a landscape), TWWP, Lublin: 79-84 (in Polish).

Chmielewski J.T., Radwan S. 1993, Zmiany stosunków ekologicznych w rejonie Poleskiego Parku Narodowego w ostatnich 75 latach (Changes in ecological relations in Polesie National Park during the last 75 years), [in:] Radwan S., Karbowski Z., Sołtys M. (eds), Ekosystemy wodne i torfowiskowe $\mathrm{w}$ obszarach chronionych (Freshwater and peat-bog ecosystems in protected areas), TWWP, Lublin: 13-25 (in Polish).

Chmielewski T. J., Sielewicz B., 1994, Ekologiczna waloryzacja terenu (Ecological evaluation of the terrain), [in:] Radwan S. (ed.), Środowisko przyrodnicze w strefie oddziaływania kanału Wieprz-Krzna (The natural environment in the zone of impact of the Wieprz-Krzna Canal), TWWP, Lublin: 9-28 (in Polish).

Chmielewski Sz., Chmielewski T. J. 2009, Analiza zmian struktury użytkowania ziemi w latach 1952-2007 (Analysis of land use structure changes in the years 19522007), [in:] Chmielewski T.J. (ed.), Ekologia krajobrazów hydrogenicznych Rezerwatu Biosfery "Polesie Zachodnie" (Ecology of hydrogenic landscapes of the "West Polesie" Biosphere Reserve), Wyd. PZN, Lublin: 47-70 (in Polish).

Dawidek J., Turczyński M., 2007, Dawne mapy topograficzne Lubelszczyzny w badaniach zmian stosunków wodnych (Former topographic maps of the Lublin region in surveys of changes in water conditions), [in:] Michalczyk Z. (ed.), Obieg wody w środowisku naturalnym i przekształconym (Water circulation in natural and transformed environment), Badania hydrograficzne w poznawaniu środowiska 8: 175-184 (in Polish, English summary).

Kaczorowska A., Kornijów R., 2012, Palaeoecological evidence for changes over the past 200 years in chironomid communities of a shallow lake exposed to cyanobacterial toxins, Aquat. Ecol. 46: 465-473.

Kowalewski G.A., Kornijów R., McGowan S., Woszczyk M., Suchora M., Bałaga K., Kaczorowska A., Gąsiorowski M., Szeroczyńska K., Wasiłowska A., (in press), Persistence of protected, vulnerable macrophyte species in a small, shallow eutrophic lake (eastern Poland) over the past two centuries: Implications for lake management and conservation, Aquat. Bot. Retrieved from http://dx.doi. org/10.1016/j.aquabot.2012.12.004 
Kowalska A., 1970, Problemy metodyczne wyznaczania obszarów bezodpływowych na Niżu Środkowopolskim (Methodological problems in defining undrained areas of Middle-European Lowland), Prz. Geogr. 42(1): 105111 (in Polish, English summary).

Kulesza P., Suchora M., Pidek I.A., Dobrowolski R., Alexandrowicz W.P., 2012, The Holocene palaeoenvironmental changes reflected in the multi-proxy studies of Lake Słone sediments (SE Poland), Palaeogeogr. Palaeocl. 363-364:79-98.

Michalczyk Z., 1994a, Wody podziemne i ich wykorzystanie (Groundwaters and their use), [in:] Radwan S. (ed.) Środowisko przyrodnicze w strefie oddziaływania kanału Wieprz-Krzna (The natural environment in the zone of impact of the Wieprz-Krzna Canal), TWWP, Lublin: 29-42 (in Polish).

Michalczyk Z., 1994b, Zmiany sieci hydrograficznej w rejonie oddziaływania kanału Wieprz-Krzna (Changes in the hydrographic network in the zone of impact of the Wieprz-Krzna Canal), [in:] Radwan S. (ed.) Srodowisko przyrodnicze w strefie oddziaływania kanału Wieprz-Krzna (The natural environment in the zone of impact of the Wieprz-Krzna Canal), TWWP Lublin; 43-46 (in Polish).

Michalczyk Z., 2009, Problems of water conditions protection and the environmental monitoring in the ŁęcznaWłodawa Lakeland, [in:] Chmielewski T.J., Sławiński C. (eds), Nature and Landscape monitoring system in the West Polesie Region, Wyd. PZN, Lublin: 152-159.

Michalczyk Z., Chmiel S., Turczyński M., 2003, Lake-level fluctuations of the lakes in the Lęczna-Włodawa Lake District, [in:] Teoreticheskie i prikladnye problemy sovremennoi limnologii (Theoretical and practical problems of contemporary limnology), Inst. Problem Ispolzovania Prirodnych Resursov i Ekologii NAN Belorusi, Minsk: 98-110.

Michalczyk Z., Chmiel S., Turczyński M., 2011, Lake water stage dynamics in the Łęczna-Włodawa Lake District in 1991-2010, Limnol. Rev. 11(3): 113-122.

Mięsiak K., Szwajgier W., Turczyński M., 2005, Environmental transformations in lake Lejno catchment basin, Limnol. Rev. 5: 175-181.

Okruszko H., Churski T., Karpińska J., 1971, Torfowiska i gytiowiska w rejonie jezior krasowych Uściwierz na Pojezierzu Łęczyńsko-Włodawskim (Peat and gyttja bogs in the region of Uściwierz karst lakes in ŁęcznaWłodawa Lake District), Zesz. Probl. Post. Nauk Rol. 107: 121-165 (in Polish).

Panasiuk A., 2012, Dzieje wsi Grabniak (History of Grabniak village). Retrieved from http://historia.urszulina. net

Przybylak R., 2010, Instrumental Observations, [in]: Przybylak, R., Majorowicz, J., Brázdil, R., Kejna, M., (eds.), The Polish Climate in the European Context. An Historical Overview, Springer, Dordrecht-Heidelberg-LondonNew York, p. 129-166.
Rostworowski J., 1882, Jeziora łęczyńsko-włodawskie (Łęczna-Włodawa Lakes), Pam. Fizjograf. 2: 76-78 (in Polish).

Sawicki L., 1928, Pułkownika Antoniego barona Mayera von Heldensfelda zdjęcia topograficzne w Polsce w latach 1801-1804 (Colonel Anthony baron Mayer von Heldensfeld's topographic works in Poland in the years 1801-1804), Pr. Inst. Geogr. UJ 10: 5-111 (in Polish, German summary).

Sposób J., Turczyński M., 2009, Przekształcenia obszarów bezodpływowych w zlewnie o wymuszonym obiegu wody: Pojezierze Łęczyńsko-Włodawskie (Transformations of undrained areas into catchments of imposed water circulation: Łęczna-Włodawa Lake District), [in:] Bogdanowicz R., Fac-Beneda J. (eds), Zasoby i ochrona wód. Obieg wody i materii w zlewniach rzecznych (Water resources and water protection. Water and matter cycling in river basins), FRUG, Gdańsk: 111-121 (in Polish, English summary).

Sposób J., Michalczyk Z., Mięskiek-Wójcik K., Turczyński M., 2010, Ocena zmian użytkowania zasobów wodnych Pojezierza Łęczyńsko-Włodawskiego na podstawie historycznych materiałów kartograficznych i zapisów kronikarskich (Evaluation of changes in the use of the Łęczna-Włodawa Lake District water resources on the basis of historical cartographic materials and chronicles), [in:] Kaniecki A., Baczyńska A. (eds), Zmiany stosunków wodnych w czasach historycznych (Changes in water conditions in historical times), Bogucki Wyd. Nauk., Poznań: 167-186 (in Polish, English summary).

Suchożebrska M., Chabudziński Ł.,2007, Anthropogenic Transformations of the Hydrographical Network in Lake Catchment Areas of the Uściwierz Lowering (ŁęcznaWłodawa Lake District), Limnol. Rev. 7: 225-231.

Tobolski K., 2000, Przewodnik do oznaczania torfów i osadów jeziornych (Handbook for the determination of peat and lake deposits), PWN, Warszawa, p. 508 (in Polish).

Turczyński M., Sobolewski W., Mięsiak-Wójcik K., 2009, Selected problems related to the demarcation of lake range in the light of field surveys, Limnol. Rev. 9: 203-214.

Wilgat T., 1954, Jeziora Łęczyńsko-Włodawskie (The Łęczna-Włodawa lakes), Ann. UMCS B 8(3): 37-121 (in Polish, English summary).

Wilgat T., 1957, Stosunki geomorfologiczne i hydrograficzne w strefie kanału Wieprz-Krzna (Geomorphologic and hydrographic conditions in the Wieprz-Krzna Canal zone), Prz. Geogr. 29(2): 259-285 (in Polish, English summary).

Wilgat T., Michalczyk Z., Turczyński M., Wojciechowski K., 1991, Jeziora Łęczyńsko-Włodawskie (The ŁęcznaWłodawa Lakes), Stud. Ośr. Dok. Fizjogr. 19: 23-140 (in Polish, English summary).

Wilgat T., 1991, Zmiany stosunków wodnych pod wpływem gospodarki (Changes in water conditions under the influence of the economy), [in:] Starkel L. (ed.), Geografia Polski: Srodowisko przyrodnicze (Geography of Poland: The natural environment), PWN, Warszawa: 205-223 (in Polish). 